\title{
Distinct expression and activity profiles of largemouth bass (Micropterus salmoides) estrogen receptors in response to estradiol and nonylphenol
}

\author{
Tara Sabo-Attwood ${ }^{1,7}$, Jason L Blum ${ }^{1}$, Kevin J Kroll ${ }^{2,3}$, Vishal Patel ${ }^{2,3}$, Detlef Birkholz ${ }^{8}$, \\ Nancy J Szabo ${ }^{3,4}$, Suzanne Z Fisher ${ }^{5}$, Robert McKenna ${ }^{5}$, Martha Campbell-Thompson ${ }^{6}$ and \\ Nancy D Denslow ${ }^{2,3,5}$ \\ ${ }^{1}$ Department of Pharmacology and Therapeutics, ${ }^{2}$ Department of Physiological Sciences, ${ }^{3}$ Center of Environmental and Human Toxicology, ${ }^{4}$ Analytical Toxicology Core Laboratory, \\ ${ }^{5}$ Department of Biochemistry and Molecular Biology and ${ }^{6}$ Department of Pathology, Immunology and Laboratory Medicine, University of Florida, PO Box 110885 , Gainesville, Florida \\ 32611, USA \\ ${ }^{7}$ Department of Environmental Health Sciences, University of South Carolina, Columbia, South Carolina, USA \\ ${ }^{8}$ Enviro-Test Laboratories, Edmonton, Alberta, Canada
}

(Correspondence should be addressed to N D Denslow; Email: ndenslow@ufl.edu)

T Sabo-Attwood and J L Blum contributed equally to this work

\begin{abstract}
The estrogen receptor (ER) signaling cascade is a vulnerable target of exposure to environmental xenoestrogens, like nonylphenol (NP), which are causally associated with impaired health status. However, the impact of xenoestrogens on the individual receptor isotypes $(\alpha, \beta a$, and $\beta b)$ is not well understood. The goal of these studies was to determine the impact of NP on largemouth bass (Micropterus salmoides) ER isotype expression and activity. Here, we show that hepatic expression levels of three receptors are not equivalent in male largemouth bass exposed to NP by injection. Transcript levels of the $\mathrm{ER} \alpha$ subtype were predominantly induced in concert with vitellogenin similarly to fish exposed to $17 \beta$-estradiol $\left(E_{2}\right)$ as measured by quantitative real-time PCR. NP also induced circulating plasma levels of estrogen, which may contribute to overall activation of the ERs. To measure the activation of each receptor isotype by $E_{2}$ and NP, we employed reporter assays using an estrogen response element (ERE)-luciferase construct. Results from these studies show that $E R \alpha$ had the greatest activity following exposure to $E_{2}$ and NP. This activity was inhibited by the antagonists ICI 182780 and ZM 189 154. Furthermore, both $\beta$ b and $\beta$ a subtypes depressed $E R \alpha$ activation, suggesting that the cellular composition of receptor isotypes may contribute to the overall actions of estrogen and estrogenic contaminants via the receptors. Results from these studies collectively reveal the differential response of fish ER isotypes in response to xenoestrogens.
\end{abstract}

Journal of Molecular Endocrinology (2007) 39, 223-237

\section{Introduction}

One synthetic chemical found in the environment that functions as a weak xenoestrogen is 4-nonylphenol (NP). NP is a microbial breakdown product of NP polyethoxylates (NPEs) that are most commonly found in industrial non-ionic surfactants and also used in the production of plastics, textiles, paints, emulsifiers, paper products, and cosmetics (Scott \& Jones 2000, Sabik et al. 2003). It is estimated that more than 500000 tons of NPEs are used annually (Scott \& Jones 2000) with $>60 \%$ entering the environment via sewage outflows (White et al. 1994, Nimrod \& Benson 1996, Canadian 2000).

In fish, the estrogenic effects of NP in vivo are well documented. These include the induction of estrogenresponsive genes in males such as vitellogenins (vtgs) and choriogenins that are involved in normal female reproduction (Allen et al. 1999, Arukwe et al. 2001, Kannan et al. 2003), impaired gonadal development (Lin \& Janz 2006), altered steroidogenesis (Harris et al. 2001), and intersex (Gray et al. 1997, Metcalfe et al. 2001, Schwaiger et al. 2002, Seki et al. 2003). These conditions have been induced in fish in controlled laboratory studies and have also been seen in wild fish found in the vicinity of sewage outflows (Allen et al. 1999, Jobling et al. 2002, Legler et al. 2002, Pettersson et al. 2005) where the main contaminants include NP.

NP has also been shown to behave as a weak estrogen in a variety of standard in vitro tests including proliferation assays using the breast cancer MCF-7 cell line (Soto et al. 1995, Blom et al. 1998, Laws et al. 2000), gene expression (Arukwe et al. 2000a, 2001, Thorpe et al. 2001), and recombinant reporter gene assays 
(Sohoni \& Sumpter 1998, Gaido et al. 2000, Yoon et al. 2000). Previous reports demonstrate that NP binds directly to the estrogen receptor (ER) and subsequently induces transcription of downstream genes regulated by this pathway (Celius et al. 1999). However, a few studies indicate that NP may also increase endogenous steroid receptor ligand levels (Thibaut \& Porte 2004, Acevedo et al. 2005, Soverchia et al. 2005), begging the question of whether NP activates the receptors directly or indirectly by increasing estrogen levels in the blood. The fact that the estrogenic effects induced by NP are inhibited by ER antagonists, suggests that NP is working at least in part via ERs (Lee 1998, Wilson et al. 2004). The use of ER antagonists in fish model systems has been minimally explored (Latonnelle et al. 2002, Hornung et al. 2003, Radice et al. 2004).

Recently, three ER isotypes have been shown to exist in fish as reported by us and others (Hawkins et al. 2000, Legler et al. 2002, Sabo-Attwood et al. 2004, Filby \& Tyler 2005). The three ERs, originally termed $\mathrm{ER} \alpha, \mathrm{ER} \beta$, and $\mathrm{ER} \gamma$, were recently renamed $\mathrm{ER} \alpha, \mathrm{ER} \beta \mathrm{b}$, and ER $\beta \mathrm{a}$ respectively, to comply with official zebrafish (zf) nomenclature (Hawkins \& Thomas 2004, Filby \& Tyler 2005). The specific role that the different ER isotypes play in the regulation of genes by $17 \beta$-estradiol $\left(\mathrm{E}_{2}\right)$ and xenoestrogens has not been determined. Studies with the human ERs (hERs) show that NP binds weakly to both $\alpha$ and $\beta$ isotypes with similar affinity, and in some cases, binding is slightly stronger to hER $\beta$ (Kuiper et al. 1998, Morito et al. 2001). However, in transfection studies, NP more strongly activates the $\mathrm{hER} \alpha$ isotype (Balaguer et al. 1999). Taken together, these results suggest that the effect of xenoestrogens on the regulation of the ER isotypes and the downstream genes they mediate in vivo are still in question.

There are limited data regarding the effects of NP on the ER isotypes in fish. Recently, one study showed that NP weakly activated the three zfERs in human embryonic kidney 293 (HEK293) cells (Legler et al. 2002). This result was similar but not identical to $\mathrm{E}_{2}$, suggesting that NP may bind and activate the ER isotypes differently than the endogenous ligand. The repercussions of these effects on genes regulated by ERs, such as ER $\alpha$ and vtg in vivoremain to be determined.

To fully understand the impact of hormonally active agents on reproduction and development, it is important to characterize effects at the molecular level in animals, particularly in those that are exposed to these compounds in the environment, like fish. The goals of this study were to measure the expression of three ER isotypes, $\alpha, \beta \mathrm{b}$, and $\beta \mathrm{a}$, and the ER regulated vtgl gene in male largemouth bass (Micropterus salmoides; LMB) following exposure to NP in vivo. In addition, we performed transactivation assays to more fully characterize the function of the three receptors in vitro in response to $\mathrm{E}_{2}, \mathrm{NP}$, and two highly used $\mathrm{ER}$ antagonists,
ICI 182780 and ZM 189 154. Male fish are appropriately used as models of xenoestrogen exposure since endogenous levels of $\mathrm{E}_{2}$ and hence the activation of ERs and levels of vtg are minimal to undetectable (data not shown) in non-exposed fish. The in vivo experiments were designed to examine the time- and dose-dependent expression of the ERs and vtg. The in vitro experiments confirmed our hypothesis that the expression of the three LMB ERs are differentially regulated by NP in the liver, with ER $\alpha$ being the most sensitive as shown previously in response to $\mathrm{E}_{2}$ (Sabo-Attwood et al. 2004).

\section{Materials and methods}

\section{Animals and exposures}

For the in vivo exposure studies, LMB was purchased from American Sport Fish Hatchery (Montgomery, AL, USA) and maintained in accordance with the NIH Guide for the Care and Use of Laboratory Animals. For all exposures, adult male LMB (>1-year old) were housed at the University of Florida Aquatic Toxicology Facility (Gainesville, FL, USA). Fish were acclimated 1 week prior to the experiments in aerated continuous flow through 105 gallon fiberglass tanks. Temperature $\left(21 \pm 2{ }^{\circ} \mathrm{C}\right)$, dissolved oxygen $(6 \cdot 5 \pm 0 \cdot 3), \mathrm{pH}(7 \cdot 2 \pm 0 \cdot 2)$, and total ammonia content (non-detectable) were monitored daily. All LMB were fed chow daily.

Each fish was weighed and treated with a single i.p. injection of $0.5 \mathrm{mg} / \mathrm{kg} \mathrm{E} \mathrm{E}_{2}$ (Sigma), $5 \cdot 0,25 \cdot 0$, or $50.0 \mathrm{mg} / \mathrm{kg} 4-\mathrm{NP}$ (>85\% para isomer; Fluka Chemicals, Milwaukee, WI, USA) or dimethyl sulfoxide (DMSO) vehicle control. At various times post-injection (24, 48, and $144 \mathrm{~h}$ ), fish were euthanized by submersion in a water bath containing 50-100 p.p.m. tricaine methanesulfonate (MS-222) followed by a sharp blow to the head followed by cervical transection following the University of Florida IACUC protocols. Blood was drawn from the caudal vein and collected in heparinized tubes for plasma $\mathrm{E}_{2}$ measurements. Bile was collected directly from the gall bladder via syringe for $\mathrm{NP}$ determinations. The livers were excised, finely chopped, immediately flash frozen in liquid nitrogen, and stored at $-80^{\circ} \mathrm{C}$ until RNA was isolated.

\section{RNA preparation and quantitative real-time PCR}

Total RNA was isolated from liver tissue and reverse transcribed as previously described (Sabo-Attwood $e t$ al. 2004). Previously validated quantitative real-time PCR (QRT-PCR) assays were used to quantify mRNA levels of $\mathrm{ER} \alpha, \beta \mathrm{a}$ (formerly ER $\gamma$ ), $\beta \mathrm{b}$, and vtg1 (Sabo-Attwood et al. 2004). Standard curves were constructed for each transcript by serial dilution of the plasmids containing 
the cloned segments for each gene. All samples were normalized to $18 \mathrm{~S}$ rRNA as previously described (Sabo-Attwood et al. 2004). The $18 \mathrm{~S}$ ribosomal primers and a labeled probe were purchased as a kit (PE Applied Biosystems, Foster City, CA, USA). All data were $\log _{10}$ transformed and graphed as the $\log _{10}$ of the copy number of each gene per $\mu \mathrm{g}$ of total RNA.

\section{Plasma $E_{2}$ measurements}

Plasma was isolated from whole blood by centrifugation. $\mathrm{E}_{2}$ was extracted from the plasma with ether following a previously published method (Oakes et al. 2005). Briefly, $500 \mu \mathrm{l}$ diethyl ether were mixed with $75 \mu \mathrm{l}$ plasma. Following vortexing, the sample was frozen in an ethanol/dry ice bath, and the ether fraction containing the organic phase was decanted into a clean, acid-washed glass tube. The process was repeated two more times and the ether fractions were pooled. Ether was allowed to evaporate and the dried residue was dissolved in $225 \mu \mathrm{l}$ Elisa Immunoassay (EIA) buffer (1 M phosphate solution (pH 7.4), containing 1\% BSA, $4 \mathrm{M} \mathrm{NaCl}, 10 \mathrm{mM}$ EDTA, and $0 \cdot 1 \%$ sodium azide). Detection of $\mathrm{E}_{2}$ was measured using an EIA kit specific for $\mathrm{E}_{2}$ (Cayman Chemicals, Ann Arbor, MI, USA) following the instructions supplied by the manufacturer. A standard curve was constructed with $\mathrm{E}_{2}$ supplied by the kit, and was used to determine the concentration of plasma $\mathrm{E}_{2}$ in each of the samples. Sample concentrations were diluted appropriately so that values could be interpolated from the standard curve and run in duplicate. All values are presented as $\mathrm{ng} / \mathrm{ml}$ of plasma.

\section{Measurements of NP in bile samples}

To detect NP in bile fluids, $100 \mu \mathrm{l}$ pooled samples per treatment group $(n=5)$ were enzymatically hydrolyzed, extracted with dichloromethane, derivatized to the corresponding acetates, and analyzed by gas chromatography/mass spectrometry (GC/MS) at the Enviro-Test Laboratories/Xenos Division (Nepean, Ont, Canada). Each fish bile sample was fortified with $10 \mu \mathrm{g}$ 4-nitrophenyl- $\beta$-D-glucopyranoside as an enzymatic hydrolysis surrogate and placed in $1 \mathrm{ml}$ of $4 \mathrm{M}$ acetate buffer (pH 5) with 10000 units of $\beta$-glucuronidase. Samples were incubated for $24 \mathrm{~h}$ at $50{ }^{\circ} \mathrm{C}$ in a sand bath with occasional shaking. After cooling, samples were fortified with $2 \mu \mathrm{g}$ 4-cumylphenol and $1.5 \mathrm{ml}$ dichloromethane. The samples were vortexed and centrifuged for $5 \mathrm{~min}$. The bottom phase was extracted and placed over a sodium sulfate column. The eluate from the column was collected and pooled from three repeated extractions. The extracts were concentrated and dried under a constant stream of nitrogen. To each sample was added 2,4,6-tribromophenol as an internal standard, pyridine, and acetic anhydride. Samples were incubated at $90^{\circ} \mathrm{C}$ for $1 \mathrm{~h}$, cooled, and concentrated. Each sample was then dissolved in $1.0 \mathrm{ml}$ toluene and analyzed by GC/MS using a DB5-MS capillary column $(30 \mathrm{~m} \times 0.25 \mathrm{~mm} \times 1 \cdot 0 \mu \mathrm{M})$. Quantitation standards were prepared from the 4-NP injected into the fish (Fluka Chemicals, Buchs, Switzerland). Quantitation was performed by the internal standard method using extracted ion chromatograms. All values were corrected for extraction and expressed as $\mu \mathrm{g}$ NP per mg of total protein.

\section{Construction of LMB ER expression constructs}

The cDNAs for each LMB ER (previously isolated in Sabo-Attwood et al. 2004) were cloned into the pCMV4 mammalian expression vector (Stratagene, La Jolla, CA, USA). The p Cytomegalovirus (pCMV)-ER constructs, a luciferase reporter driven by a two tandem repeat of the Xenopus vtg A2 promoter ERE (AGGTCAcagTGACCT; gift from Dr Pierre Chambon) and a renilla luciferase construct (pRL-TK, Promega) were purified using an endotoxin-free maxi-prep kit (Qiagen).

\section{Growth and maintenance of hepatocellular carcinoma (HepG2) cells}

HepG2 cells purchased from American Type Culture Collection were maintained in Earle's minimal essential medium (EMEM) supplemented with $0 \cdot 1 \mathrm{mM}$ essential amino acids (Sigma-Aldrich, St Louis, MO, USA), $2 \cdot 0 \mathrm{mM}$ L-glutamine, $1.0 \mathrm{mM}$ sodium pyruvate, $1.5 \mathrm{~g} / 1$ sodium bicarbonate, antibiotic/antimycotic (Hyclone, Logan, UT, USA), and $10 \%$ fetal bovine serum (Fisher Scientific, Hampton, NH, USA). The cells were cultured in a humidified incubator at $37^{\circ} \mathrm{C}$ in an atmosphere of $5 \%$ $\mathrm{CO}_{2}$ and air.

\section{Transient transfection assay in HepG2 cells}

HepG2 cells were seeded at a density of 100000 cells per well in a 24-well plate in normal medium. Twenty four hours following plating, the culture medium was aspirated, the cell monolayers were washed once with Hank's balanced salt solution, and the medium was replaced with media containing $10 \%$ charcoal-stripped serum. The transfection mix was made up in serum-free medium. The vector transfection mix consisted of $0.5 \mu \mathrm{g}$ ER construct and $1 \mu \mathrm{g}$ ERE-luciferase construct per well while the Renilla construct was used at $0 \cdot 2 \mu \mathrm{g}$ per well. Fugene 6 (Roche) was the transfectant and it was used at a ratio of 3:1 $\mu \mathrm{g}$ (Fugene:DNA). Each transfection mix was made up to $100 \mu \mathrm{l}$ per well and was incubated for $15 \mathrm{~min}$ at room temperature. One hundred microlitres of each transfection mixture were added dropwise to the wells as directed by the manufacturer. Experiments testing the 
effect of ER mixtures were prepared similarly, except the total amount of DNA in the ER tube was increased to a total of $2 \mu \mathrm{g}$ using the empty pCMV4 expression vector to maintain a constant mass of DNA.

Eighteen hours following transfection, the medium was aspirated and replaced with charcoal-stripped medium containing the respective treatments $\left(\mathrm{E}_{2}(10\right.$, $25,50,75,100,500$, and $1000 \mathrm{nM})$, NP $(0 \cdot 1,0 \cdot 5,1,5$, and $10 \mu \mathrm{M})$, ICI $182780(5 \mu \mathrm{M})$, ZM 189154 (5 or $10 \mu \mathrm{M})$ ) keeping the amount of vehicle constant at either $0 \cdot 1 \%$ for single chemicals or $0 \cdot 2 \%$ for multiple chemicals in the ER antagonist assays. Treatments were allowed to continue for $48 \mathrm{~h}$ at which time the medium was removed, and the cells rinsed once with PBS (137 mM NaCl, 2.9 mM KCl, $8.1 \mathrm{mM} \mathrm{Na} \mathrm{PO}_{4}$, and $1.5 \mathrm{mM} \mathrm{KH}_{2} \mathrm{PO}_{4}(\mathrm{pH} \mathrm{7.5)})$. The cells were then lysed at room temperature using passive lysis buffer (Promega, Fitchburg, WI, USA) for about $20 \mathrm{~min}$ on a shaker. Twenty microliters of lysate were then added to wells of a 96-well Lumitrac 200 plate (Greiner Bio-One, Germany) for assay of both firefly and renilla luciferase activities using the Dual Luciferase Reporter assay system (Promega). The lysates were measured on a PlateLumino luminometer (Stratec Biomedical Systems AG, Birkenfeld, Germany) with two reagent injectors.

\section{Model construction}

The amino acid sequences used to make the structural models of LMB ER $\alpha, E R \beta b$, and ER $\beta$ a were obtained from the National Center for Biotechnology Information (NCBI) database (accession numbers AAG44622, AAO39210, and AAO39211 respectively). Models of the LMB ER ligand-binding domains (LBDs) were built with the program Swiss-Model using the Expasy web server, http://swissmodel.expasy.org (Peitsch 1996, Guex et al. 1999, Schwede et al. 2003). The template used for the construction of all three LMB ER domains was the crystal structure of hER $\alpha$ (PDB accession code: 1A52; Tanenbaum et al. 1998). Modeling of $\mathrm{E}_{2}$ into the LMB ER LBDs was performed by least-squares fitting of each individual model onto the crystal structure of $\mathrm{hER} \alpha$ in complex with $\mathrm{E}_{2}$. All model visualization and manipulation were done with the interactive graphics program Coot (Emsley \& Cowtan 2004). The molecular interactions of hER $\alpha$ and $\mathrm{E}_{2}$ were determined with BobScript and rendered with Raster3D (Esnouf 1999).

\section{Statistical analysis}

For QRT-PCR, the 18S rRNA-normalized copy number for each gene was $\log _{10}$ transformed. The transformed values were then compared by ANOVA using treatment, time, and the interaction effect treatment $\times$ time (where appropriate). Where the effect of treatment was found to be significant $(P \leq 0 \cdot 05)$, differences between the treatments were determined by Duncan's multiple range test (DMRT). When the effect of the treatment $\times$ time interaction was significant, the data were sorted by time and the treatments were compared by DMRT $(\alpha=0 \cdot 05)$.

Firefly luciferase values were normalized to the respective Renilla luciferase values. For single chemicals, the fold change of the normalized luciferase values was computed by dividing each reading by the average of the vehicle response. For experiments looking at ER interactions, the fold changes were computed as with the single chemical experiments but used the empty pCMV4 expression as control. In experiments using ER inhibitors, the values of the double vehicle were used as the control.

After the fold changes were computed, the data were analyzed by ANOVA using treatment, experiment, and the interaction as the main effects using the Statistical Analysis System 8.1 (SAS Institute Inc., Cary, NC, USA). When the treatment value was found to be significant $(P \leq 0 \cdot 05)$, further testing was done by DMRT. Data presented are means \pm s.E.M. and are the result of at least three independent experiments with three wells per treatment per plate.

\section{Results}

\section{NP increases the expression of ER $\alpha$ and vtg1 in LMB liver tissue}

Previously, we have shown that $\mathrm{E}_{2}$ enhances the expression of $\mathrm{ER} \alpha$ and $\operatorname{vtg} 1$ in LMB liver tissue in a dose-dependent manner, and induced ER $\beta$ a (previously called ER $\gamma$ ) expression only at the highest dose of $\mathrm{E}_{2}$ tested $(2.5 \mathrm{mg} / \mathrm{kg}) . \mathrm{E}_{2}$ did not enhance the expression of ER $\beta b$ in those studies (Sabo-Attwood et al. 2004). To determine whether NP would have a similar effect on the transcription of these genes, we treated LMB with three doses NP $(5 \cdot 0,25 \cdot 0$, or $50 \cdot 0 \mathrm{mg} / \mathrm{kg})$ and compared the effects with $0.5 \mathrm{mg} / \mathrm{kg} \mathrm{E}$. Exposure to 25 and $50 \mathrm{mg} / \mathrm{kg}$ NP significantly increased levels of $E R \alpha$, with the highest dose of NP increasing levels comparable with $0.5 \mathrm{mg} / \mathrm{kg}$ $\mathrm{E}_{2}$ (Fig. 1A). No significant differences were observed in the expression levels of ER $\beta$ a or ER $\beta b$ at any of the doses of NP tested (Fig. 1B and C).

vtgl, a gene known to be regulated by ERs and a common biomarker of estrogenic exposure, has previously been shown to be dose-responsive to $\mathrm{E}_{2}$ in LMB (Bowman et al. 2002, Sabo-Attwood et al. 2004). Figure 1D shows that NP also increased the expression of vtg1 in a dose-responsive manner, with the two highest doses (25 and $50 \mathrm{mg} / \mathrm{kg}$ ) giving statistically significant changes when compared with control. The 

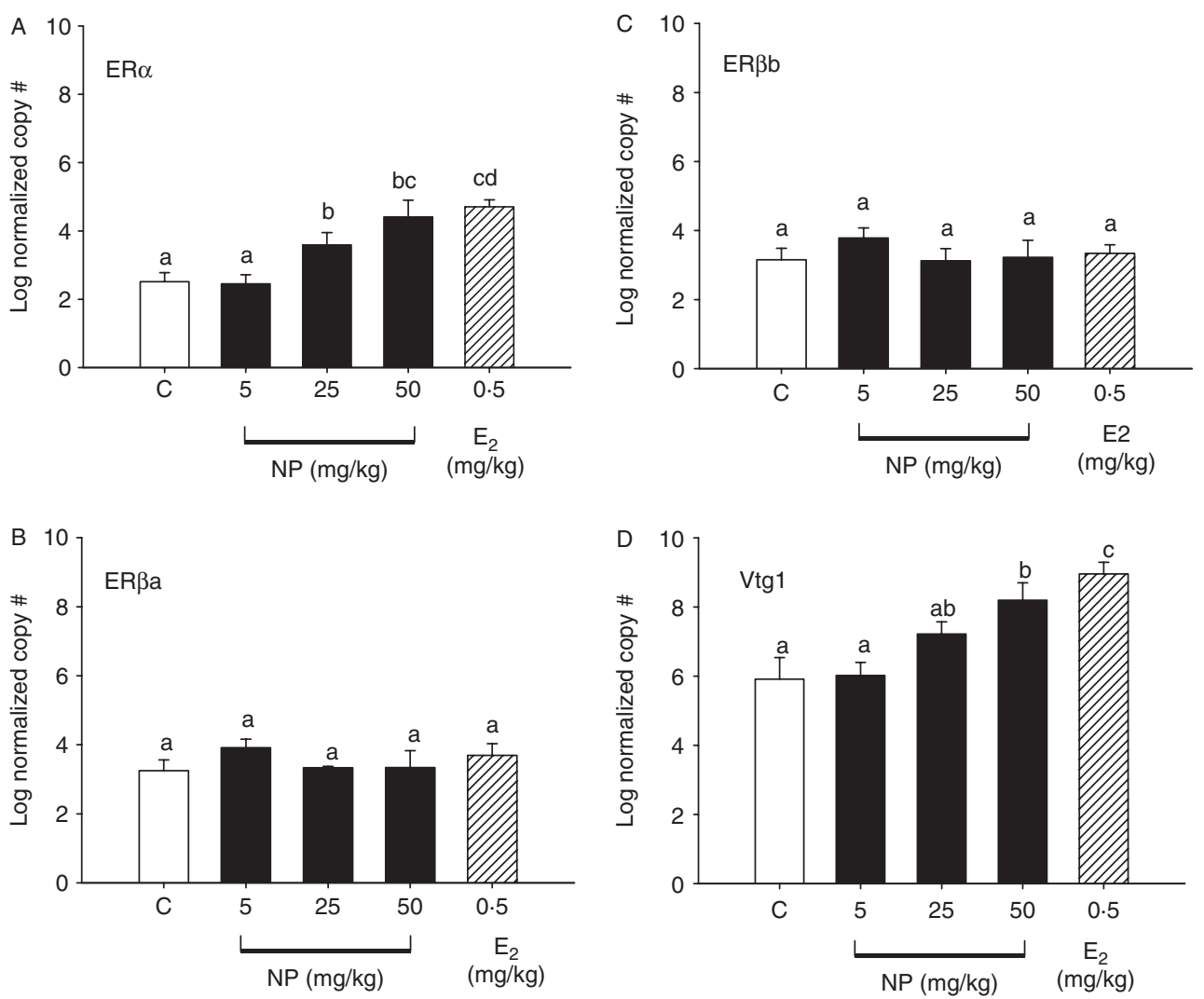

Figure 1 Expression of ER isotypes and vtg1 in LMB livers following exposure to varying doses of NP or a single dose of $\mathrm{E}_{2}$. Livers of LMB males ( $n=5$ per group) were injected with the control vehicle DMSO (C) (clear bars), NP $(5 \cdot 0,25 \cdot 0$, and $50.0 \mathrm{mg} / \mathrm{kg}$; solid bars), or $0.5 \mathrm{mg} / \mathrm{kg} \mathrm{E}$ (cross-hatched bars) by injection (i.p.) were assayed after $24 \mathrm{~h}$ for the expression of (A) ER $\alpha$, (B) ERßa, (C) ER $\beta b$, and (D) vtg1 by QRTPCR. Raw data were first normalized to $18 \mathrm{~S}$ rRNA, converted to copy number and then $\log _{10}$ transformed. Data are presented as mean $\log _{10}$ of the normalized copy number per $\mu \mathrm{g}$ of total RNA \pm S.E.M. Treatments whose means were significantly different are represented with different letters.

highest levels of vtg1 observed overall occurred following exposure to $0.5 \mathrm{mg} / \mathrm{kg} \mathrm{E}_{2}$.

\section{Time-course profiles of LMB ERs and vtg1 in response to $E_{2}$ and NP}

Expression levels of the three ERs in the liver were measured as a function of time at 24-, 48-, and 144-h postexposure to single injections of NP $(5,25$, and $50 \mathrm{mg} / \mathrm{kg})$ or $\mathrm{E}_{2}(0 \cdot 5,1 \cdot 0$, and $2.5 \mathrm{mg} / \mathrm{kg} ;$ Fig. 2). These times were selected based on previous studies that show peak expression of ER $\alpha$ between 24 and $48 \mathrm{~h}$, returning to basal levels by $5-7$ days post-treatment (Bowman et al. 2002). We also wanted to assess whether the ER $\beta$ isoforms were responsive to $\mathrm{E}_{2}$ and $\mathrm{NP}$ at other time points. Figure 2 shows that $\mathrm{ER} \alpha$ transcriptional levels are significantly increased at all of the time points analyzed following exposure to the highest dose of $\mathrm{E}_{2}(2 \cdot 5 \mathrm{mg} / \mathrm{kg}$; Fig. 2A). Although peak levels were seen at $24 \mathrm{~h}$, the expression levels remained elevated at 48 and $144 \mathrm{~h}$ when compared with controls. Significantly increased levels were also observed for the mid $(1.0 \mathrm{mg} / \mathrm{kg})$ and low $(0.5 \mathrm{mg} / \mathrm{kg})$ doses of $\mathrm{E}_{2}$ with peak levels occurring at 24-h post-exposure. Levels of $\mathrm{ER} \alpha$ were also significantly induced by NP, but only at the two highest doses tested (Fig. 2B). In addition, the levels of ER $\alpha$ were sustained by NP since peak levels were observed at 24 and $48 \mathrm{~h}$ compared with the pattern elicited by $\mathrm{E}_{2}$.

$\mathrm{ER} \beta \mathrm{a}$ was upregulated by $\mathrm{E}_{2}$ only at the highest dose $(2.5 \mathrm{mg} / \mathrm{kg})$ and only at 24-h post-exposure (Fig. 2C). The other concentrations of $\mathrm{E}_{2}$ and all concentrations of NP failed to significantly induce the expression of this receptor (Fig. 2C and D). ER $\beta$ b was unaltered at all times and doses of both $\mathrm{E}_{2}$ and NP (Fig. 2E and F). While the overall pattern of induction for ER $\alpha$ was similar in $\mathrm{NP}$ and $\mathrm{E}_{2}$ exposed fish, the magnitude of induction with NP was comparatively less. The data reveal that a dose of NP that is 100 times higher than $\mathrm{E}_{2}$ elicits a similar magnitude of induction of ER $\alpha$ transcriptional levels. 

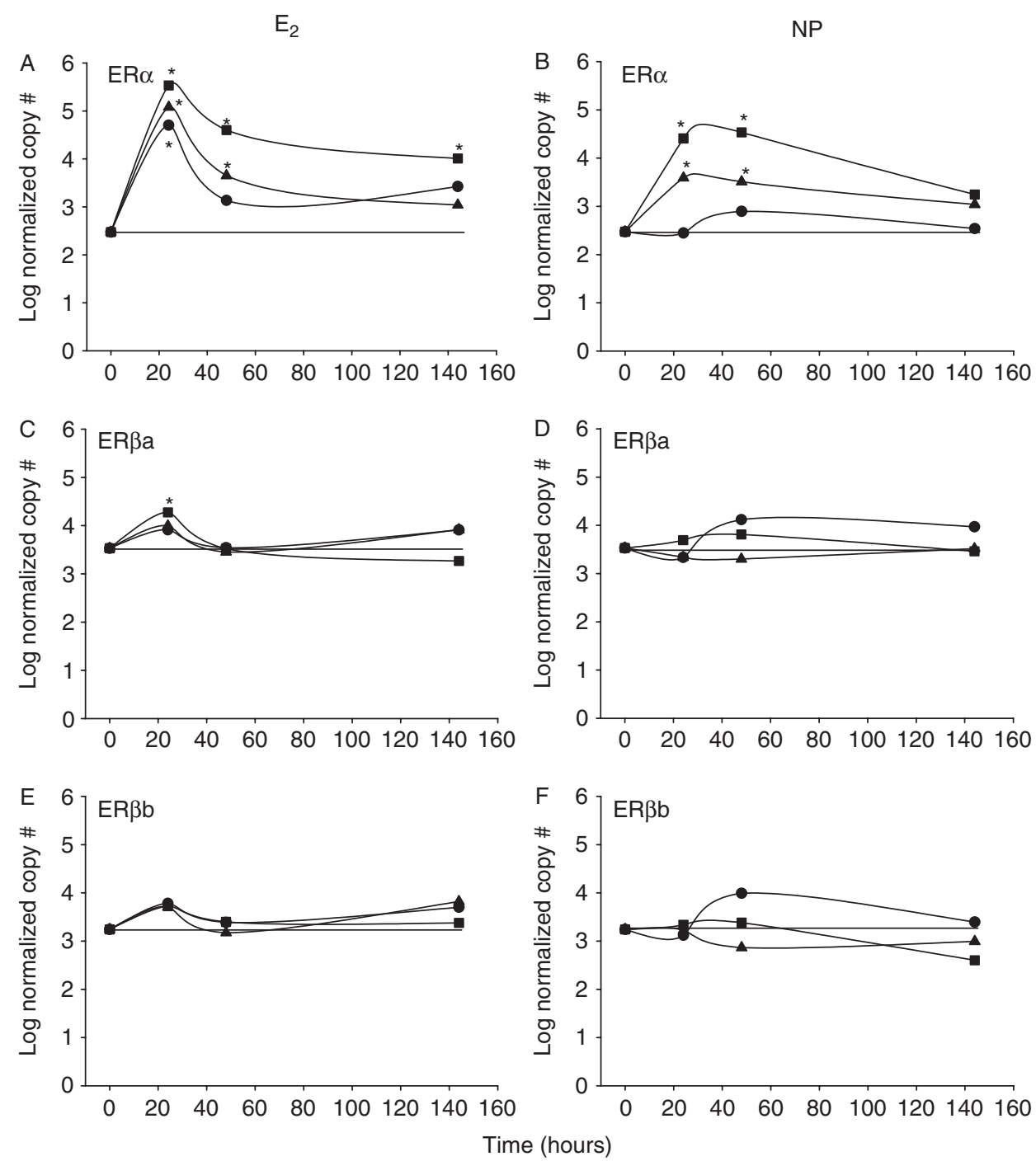

Figure 2 Time course of ER isotype expression following exposure to $E_{2}$ and NP. Livers from male LMB ( $n=5$ per group) injected with vehicle (DMSO), $0.5 \mathrm{mg} / \mathrm{kg} \mathrm{E}_{2}$ (circles), $1.0 \mathrm{mg} / \mathrm{kg} \mathrm{E}_{2}$ (triangles), $2.5 \mathrm{mg} / \mathrm{kg} \mathrm{E} \mathrm{E}_{2}$ (squares) or $5 \mathrm{mg} / \mathrm{kg} \mathrm{NP}$ (circles), $25 \mathrm{mg} / \mathrm{kg} \mathrm{NP}$ (triangles), and $50.0 \mathrm{mg} / \mathrm{kg} \mathrm{NP}$ (squares) by injection (i.p.) were assayed at 24, 48, and $144 \mathrm{~h}$ following treatment for the expression of $E R \alpha(A$ and $B), E R \beta a$ ( $B$ and $C)$, and $E R \beta b$ (E and F) by QRT-PCR. All data are presented as the $\log _{10}$ transformed mean number of copies per $\mu \mathrm{g}$ of total RNA. Statistically significant differences between control and treated fish $(P \leq 0.05)$ for each time point are represented with an asterisk.

Figure 3 shows that NP increased the expression of vtg1 mRNA by $24 \mathrm{~h}$ and then further increased it at 48 -h post-injection, indicating that the effect of $\mathrm{NP}$ on this gene was sustained similarly to the effects on ER $\alpha$. With $0.5 \mathrm{mg} / \mathrm{kg} \mathrm{E}_{2}$ on the other hand, vtg1 expression peaked within the first $24 \mathrm{~h}$ and then significantly declined by $48 \mathrm{~h}$, although it remained elevated when compared with control values. At $48 \mathrm{~h}$, the levels of vtg1 in response to $\mathrm{E}_{2}$ were comparable with the expression elicited by $50 \mathrm{mg} / \mathrm{kg} \mathrm{NP}$ at $24 \mathrm{~h}$. As seen for ER $\alpha$, the peak levels of vtg1 obtained following exposure to $E_{2}$ and
NP were similar, indicating that a dose of NP 100 times greater than $E_{2}$ is required to elicit similar transcriptional levels of this gene. By $144 \mathrm{~h}$, the expression of vtg1 returned to control levels for both chemicals.

\section{Determination of NP metabolites in LMB bile}

We measured concentrations of NP metabolites in pooled samples of bile from fish exposed to $50 \mathrm{mg} / \mathrm{kg}$ NP and the results are presented in Table 1. The levels 


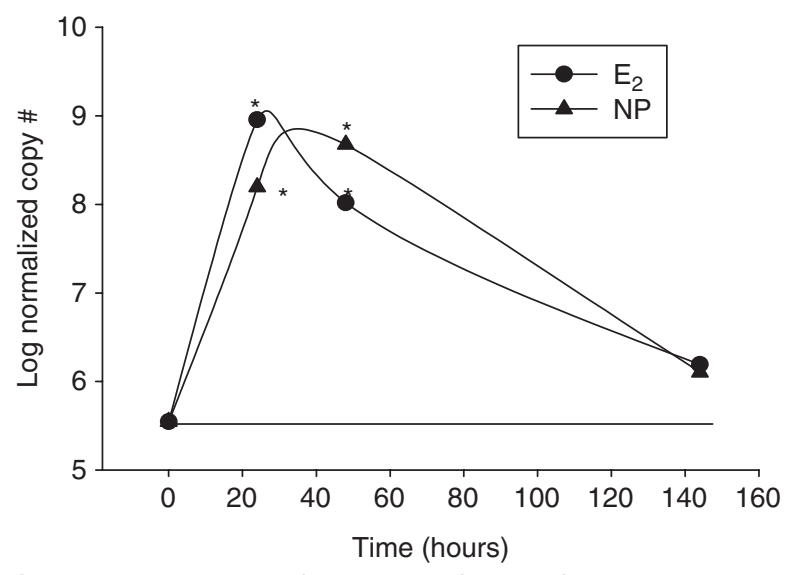

Figure 3 Time course of expression for vtg1 following treatment with $\mathrm{E}_{2}$ and NP. The livers of male LMB ( $n=5$ per group) injected with vehicle control (DMSO), $50.0 \mathrm{mg} / \mathrm{kg} \mathrm{NP}$ (triangles), or $2.5 \mathrm{mg} / \mathrm{kg} \mathrm{E} \mathrm{E}_{2}$ (circles) were assayed at 24,48 , and $144 \mathrm{~h}$ for changes in the expression of the vtg1 mRNA by QRT-PCR. Changes in expression are presented as the $\log _{10}$ of the transformed number of copies per $\mu \mathrm{g}$ of total RNA. Statistically significant differences $(P \leq 0.05)$ between control and treated fish for each time point are represented with an asterisk.

were similar at $24(1083.6 \mu \mathrm{g} \mathrm{NP} / \mathrm{mg}$ total bile protein) and $48 \mathrm{~h}(995.5 \mu \mathrm{g} \mathrm{NP} / \mathrm{mg}$ total bile protein), suggesting slow clearance of NP via biliary excretion.

\section{Plasma levels of $E_{2}$ are increased by NP}

Although it has been suggested that xenoestrogens bind directly to ERs to activate gene transcription, it has also been shown that they can alter the synthesis or biotransformation of endogenous hormones by alternative pathways. Figure 4 shows that the highest dose of NP used in these experiments significantly increased $\mathrm{E}_{2}$ concentrations in the blood to $\sim 1.0 \mathrm{ng} / \mathrm{ml}$ by $24 \mathrm{~h}$. This was the dose and time where peak expression of ER $\alpha$ and $v \operatorname{tg} 1$ was observed. As expected, there was a significant dose-dependent increase in plasma $\mathrm{E}_{2}$ levels when fish were injected with $\mathrm{E}_{2}(0 \cdot 5,1 \cdot 0$, and $2.5 \mathrm{mg} / \mathrm{kg})$.

\section{Activation of LMB ER $\alpha$, ER $\beta a$, and ER $\beta b$ in HepG2 cells by $\mathrm{E}_{2}$}

To assess the activity of the ERs in response to varying concentrations of $\mathrm{E}_{2}$, each $\mathrm{ER}$ in combination with an

Table 1 Measurement of 4-nonylphenol (NP) in $\mu \mathrm{g} / \mathrm{g}$ in the bile

\begin{tabular}{|c|c|c|}
\hline & Control & $50 \mathrm{mg} / \mathrm{kg} \mathrm{NP}$ \\
\hline & $1 \cdot 12$ & 1050 \\
\hline $48 \mathrm{~h}$ & $2 \cdot 28$ & 905 \\
\hline
\end{tabular}

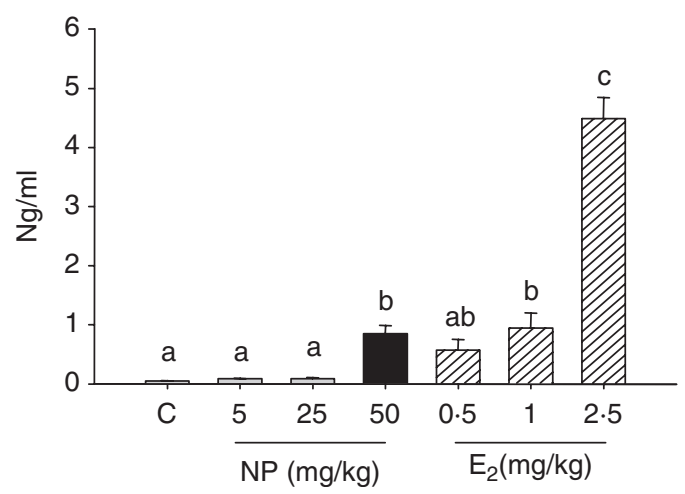

Figure 4 Quantification of plasma $E_{2}$ in $L M B$ exposed to $E_{2}$ and NP. Plasma was isolated from LMB males $(n=5$ per group) injected with the vehicle control DMSO (C) (clear bar), NP $\left(5.0,25.0\right.$, and $50.0 \mathrm{mg} / \mathrm{kg}$; solid bars) or $\mathrm{E}_{2}(0.5,1.0$, and $2.5 \mathrm{mg} / \mathrm{kg}$; hatched bars) $24-\mathrm{h}$ post-exposure. The levels of $E_{2}$ were measured by EIA and are expressed as mean $\mathrm{ng} / \mathrm{ml}$ plasma. Statistically significant differences $(P \leq 0.05)$ between treatments are represented with letters.

ERE-luciferase reporter plasmid was transfected into human HepG2 cells. This cell line contains undetectable levels of endogenous hERs (data not shown) so it is an appropriate cell line in which to assess the activity of LMB ERs. Following exposure to $\mathrm{E}_{2}(10-1000 \mathrm{nM})$ or ethanol as a control $(0 \cdot 1 \%)$, each of the three ERs was responsive in a dose-dependent manner as measured by activation of transcription of the luciferase reporter gene (Fig. 5A). ER $\alpha$ was the most sensitive receptor becoming distinct from vehicle at $25 \mathrm{nM}$, and it went on to reach the greatest magnitude over the ethanol control. Each of the ER $\beta$ s required $50 \mathrm{nM} \mathrm{E}_{2}$ for receptor activity, with $\mathrm{ER} \beta \mathrm{b}$ reaching a greater level of transcriptional activation than $\mathrm{ER} \beta \mathrm{a}$. The $\mathrm{EC}_{50}$ value obtained for $\mathrm{ER} \alpha$ was $106 \cdot 8 \mathrm{nM}$ with a $95 \%$ confidence interval (CI) of $76 \cdot 66-148 \cdot 9 \mathrm{nM}$. For the ER $\beta \mathrm{s}$, the $\mathrm{EC}_{50}$ values were similar with ER $\beta \mathrm{a}$ at $125.7 \mathrm{nM}$ and $\mathrm{ER} \beta \mathrm{b}$ at $134.8 \mathrm{nM}$. ERßa and $\mathrm{ER} \beta \mathrm{b}$ had $95 \%$ CIs at the $\mathrm{EC}_{50}$ of $67 \cdot 82-232 \cdot 9$ and $88 \cdot 24-205 \cdot 8 \mathrm{nM}$ respectively.

\section{Activation of LMB ER $\alpha$, ERßa, and ERßb in HepG2 cells by NP}

In order to determine the effect of NP on ER activity, the LMB ERs were transfected into HepG2 cells as described previously and the cells were treated with $0 \cdot 1-10 \mu \mathrm{M} N \mathrm{NP}$ or ethanol vehicle $(0 \cdot 1 \%)$. Figure 5B shows the results of these experiments. ER $\alpha$ and ER $\beta b$ were most sensitive to NP. ER $\alpha$ responded at $0 \cdot 1 \mu \mathrm{M}$ and continued to rise in activity through $5 \mu \mathrm{M}$ where it reached a plateau of about $9 \cdot 5$-fold activity over vehicle. ER $\beta \mathrm{b}$ also responded at $0 \cdot 1 \mu \mathrm{M}$ and reached a plateau at $1 \cdot 0 \mu \mathrm{M}$ resulting in $7 \cdot 5$-fold activity over vehicle. ER $\beta \mathrm{a}$ did not respond as the dose-response curve was not 


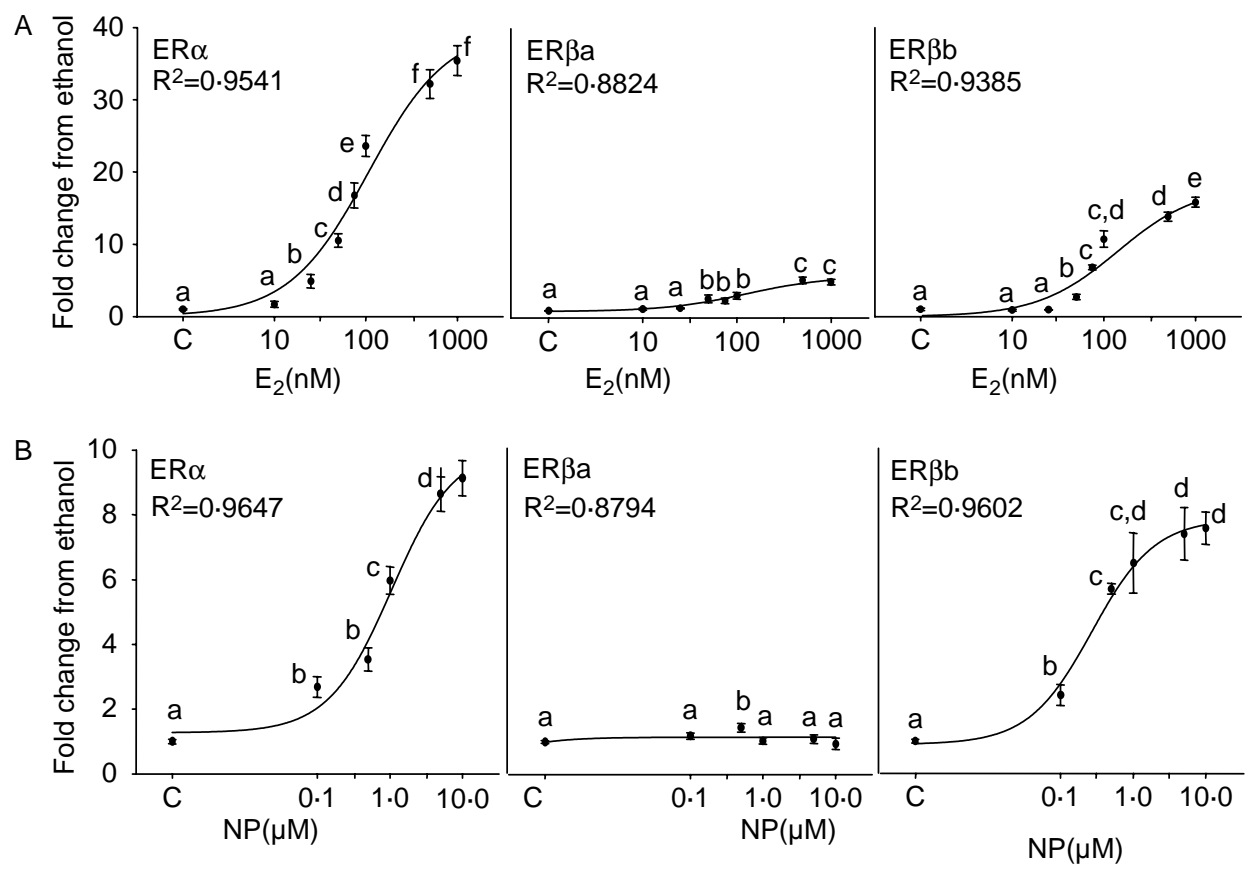

\begin{tabular}{|c|c|c|}
\hline & $\underline{E^{C}}{ }_{50} \underline{\text { Value }} \mathrm{E}_{2}$ & $95 \% \mathrm{Cl}$ of $\mathrm{EC}_{50}$ \\
\hline $\mathrm{ER} \alpha$ & $\overline{10} 6 \cdot 8 \mathrm{nM}$ & $76 \cdot 66-148 \cdot 9 \mathrm{nM}$ \\
\hline $\mathrm{ER} \beta \mathrm{a}$ & $125 \cdot 7 \mathrm{nM}$ & $67 \cdot 82-232 \cdot 9 \mathrm{nM}$ \\
\hline$E R \beta b$ & $134 \cdot 8 \mathrm{nM}$ & $88 \cdot 24-205 \cdot 8 \mathrm{nM}$ \\
\hline & $\underline{\mathrm{EC}_{50} \text { Value NP }}$ & $95 \% \mathrm{Cl}$ of $\mathrm{EC}_{50}$ \\
\hline $\mathrm{ER} \alpha$ & $\overline{10} 52 \mathrm{nM}$ & $684.8-1617 n \bar{M}$ \\
\hline $\mathrm{ER} \beta \mathrm{a}$ & - & - \\
\hline$E R \beta b$ & $270 \cdot 3 \mathrm{nM}$ & $169 \cdot 5-430 \cdot 8 \mathrm{nM}$ \\
\hline
\end{tabular}

Figure 5 Activation of LMB ERs in response to $E_{2}$ and NP. Eighteen hours following transfection, cells were treated with $(A) E_{2}(10,25,50,75,100,500$, or $1000 \mathrm{nM})$ or $(B) N P(0 \cdot 1,0 \cdot 5,1,5$, or $10 \mu M)$ in a vehicle of ethanol $(0 \cdot 1 \%)$ in charcoal-stripped serum containing medium. Cells were lysed $48 \mathrm{~h}$ following treatment with $100 \mu \mathrm{l}$ passive lysis buffer and $20 \mu \mathrm{l}$ cellular lysate were assayed for firefly and renilla luciferase activities. The ratio of firefly luciferase to renilla luciferase was computed for each sample, and the fold change of each chemical concentration was calculated compared with vehicle. The data were analyzed by ANOVA and differences between concentrations were determined by Duncan's multiple range test $(\alpha=0.05)$. Data presented are the means \pm S.E.M. from triplicate wells from three independent experiments. Means with different letters were found to be significantly different.

(C) Calculated $\mathrm{EC}_{50}$ from the curves presented above.

different to that of the empty pCMV expression vector (data not shown).

$\mathrm{ER} \alpha$ was found to have an $\mathrm{EC}_{50}$ of $1.05 \mu \mathrm{M}$ with a $95 \%$ CI of 0.69-1.62 $\mu \mathrm{M}$. No $\mathrm{EC}_{50}$ value could be calculated for ERßa, due to both the lack of significant effect of treatment and the near linear horizontal slope of the dose-response curve. ER $\beta \mathrm{b}$, on the other hand, had an $\mathrm{EC}_{50}$ of $0 \cdot 27 \mu \mathrm{M}$ with a range of $0 \cdot 17-0 \cdot 43 \mu \mathrm{M}$. Based on $\mathrm{EC}_{50}$ values, $\mathrm{NP}$ was found to be about $10 \%$ as potent an agonist for $E R \alpha$ as $E_{2}$, while it was found to be about $50 \%$ as potent as $\mathrm{E}_{2}$ for $\mathrm{ER} \beta \mathrm{b}$ (Fig. $5 \mathrm{C}$ ).

\section{Effects of antagonists ICI 182780 or ZM 189154 on ER activation by $E_{2}$}

To further characterize the LMB ERs, transfected

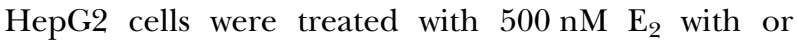
without the ER antagonists ICI 182780 (ICI; $5 \mu \mathrm{M}$ ) or ZM $189154(\mathrm{ZM} ; 5$ or $10 \mu \mathrm{M})$ based on concentrations used in other fish models (Hornung et al. $2003)$, or with ethanol as vehicle $(0 \cdot 2 \%)$. Figure 6 shows that ICI at $5 \mu \mathrm{M}$ (tenfold molar excess over $\mathrm{E}_{2}$ ) was able to completely inhibit $\mathrm{ER} \alpha$ activity to the level of vehicle alone. ICI was unable to significantly 


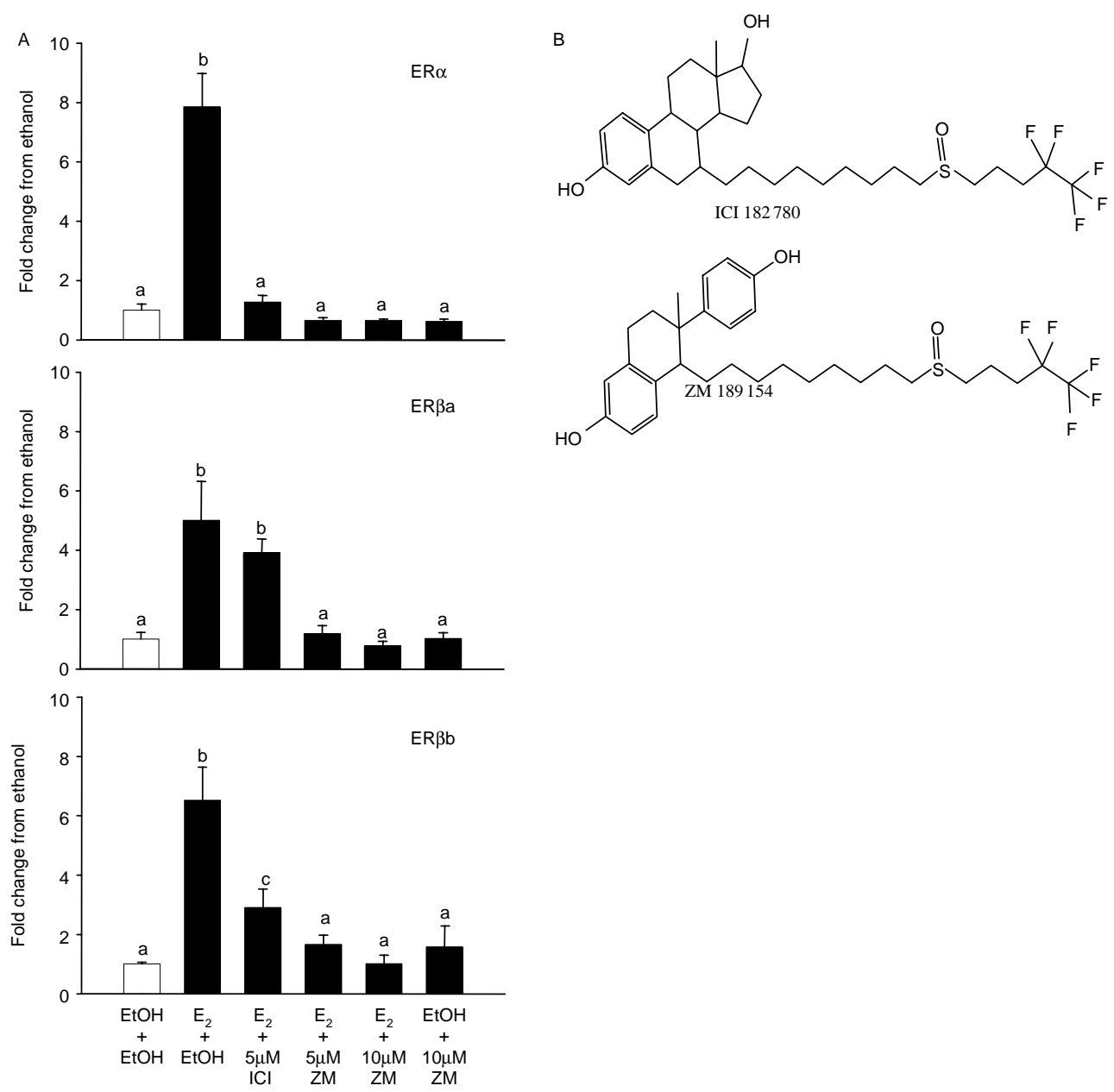

Figure 6 Inhibition of LMB ER activity by antagonists. (A) Cells were transfected as described in Fig. 5. Eighteen hours after transfection, the cells were treated with $0.5 \mu \mathrm{M} \mathrm{E} \mathrm{E}_{2}$ with or without the inhibitors ICI $182780(5 \mu \mathrm{M})$ or ZM $189154(5$ or $10 \mu \mathrm{M})$ in a vehicle of ethanol $(0.2 \%)$. The fold change values were compared by ANOVA and when the treatment effect was found to be significant $(P \leq 0.05)$, differences between the treatments were determined by Duncan's multiple range test with $\alpha=0.05$. Data are presented as the mean \pm S.E.M. from triplicate wells from three independent experiments. Bars with different letters were found to be significantly different.

(B) Chemical structures of the antagonists.

decrease the activity of ERßa, while it was able to decrease $\mathrm{ER} \beta \mathrm{b}$ activity by $\sim 55 \%$ versus $\mathrm{E}_{2}$ alone. $\mathrm{ZM}$ at either concentration (10- or 20-fold molar excess over $\mathrm{E}_{2}$ ) was able to completely inhibit the transcriptional activation for all three ERs stimulated by $\mathrm{E}_{2}$. On its own, ZM was unable to stimulate transactivation of any of the ERs, showing that it acts as a pure antagonist for this response.

\section{Modulation of ER $\alpha$ activity by ERßa or ER $\beta b$}

In certain tissue types, both ER $\alpha$ and ER $\beta$ are found co-expressed and it has been hypothesized that their differential response to estrogenic ligands in control of downstream transcriptional activity is regulated, in part, by the formation of ER heterodimers. To address this possibility, a set of experiments were performed to measure the effect of increasing the amount of either ERßa or ER $\beta b$ against a constant amount of ER $\alpha$. Figure 7 shows that in both sets of experiments, $\mathrm{ER} \alpha$ alone stimulated a 16 -fold increase in transcriptional activity whereas ER $\beta a$ and ER $\beta b$ alone were each able to stimulate a four- and eightfold increase in activity respectively. The addition of $0 \cdot 1 \mu \mathrm{g} \quad(20 \%$ of $\mathrm{ER} \alpha)$ ER $\beta$ a resulted in $\sim 37.5 \%$ decrease in activity, while the addition of $0.1 \mu \mathrm{g}$ ER $\beta \mathrm{b}$ resulted in $\sim 25 \%$ decrease in activity. Adding $0.25 \mu \mathrm{g}(50 \%$ of $\mathrm{ER} \alpha)$ ER $\beta$ a resulted in a $44.4 \%$ decrease of overall activity, while the addition of 

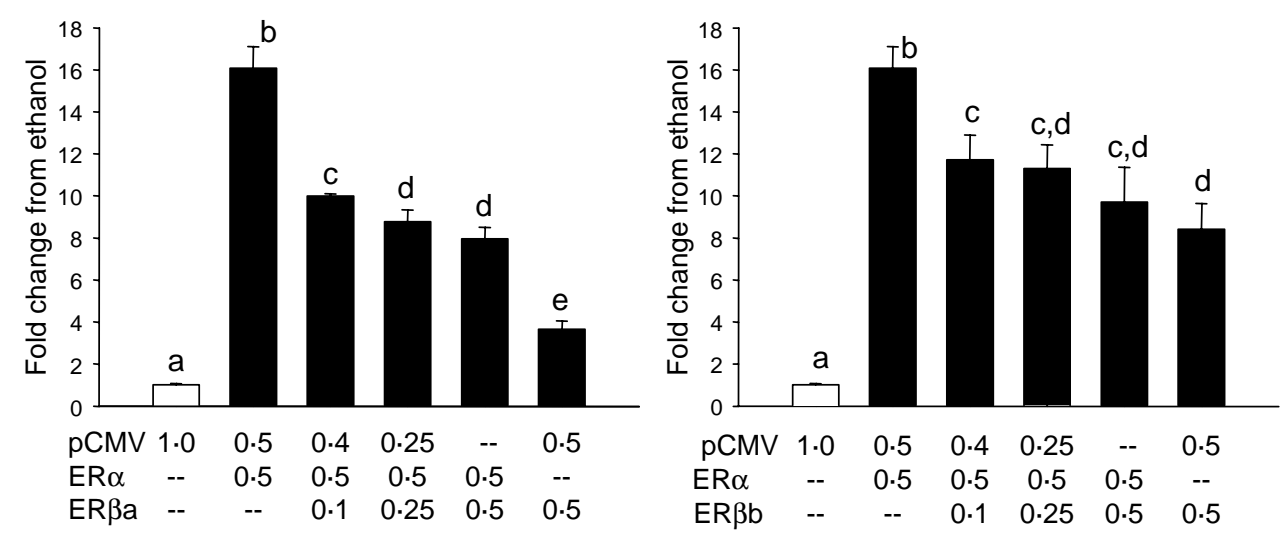

Figure $7 \mathrm{LMB} E R \beta a$ and $E R \beta b$ modulate $E R \alpha$ activity. Cells were transfected with varying amounts of the three LMB ERs as described in Fig. 5. Following transfection, the cells were treated with $0.5 \mu \mathrm{M} \mathrm{E} \mathrm{E}_{2}$ in ethanol $(0.1 \%)$ or with ethanol alone in charcoal-stripped serum containing medium. The data were analyzed for the effect of treatment by ANOVA and when differences were found, the different expression vector combinations were compared by Duncan's multiple range test $(\alpha=0.05)$. Vector combinations with different letters were found to be significantly different. Data are presented as the mean \pm S.E.M. from triplicate wells from two independent experiments.

$0 \cdot 25 \mu \mathrm{g}$ ER $\beta \mathrm{b}$ resulted in no greater loss in activity. Co-transfection of an equal amount of either ER $\beta$ or $\mathrm{ER} \alpha$ resulted in no further significant decrease in activity.

\section{Model of ER $\alpha$ with $E_{2}$}

Structural models of proteins may help us explain differences in ER activity in response to estrogens. The percentage sequence identity among the LMB $\mathrm{ER} \alpha, \mathrm{ER} \beta \mathrm{b}$, and ER $\beta \mathrm{a}$ LBDs compared with that of the $\mathrm{hER} \alpha$ is 46,45 , and $44 \%$ respectively. A leastsquares fit of the three LMB ER LBD models resulted in an average root-mean-square deviation, for all atoms, of $<1 \cdot 0 \AA$. Using the hER as a model receptor, we show which amino acids make contact with $\mathrm{E}_{2}$ (Fig. 8). This model predicts residues from $\mathrm{hER} \alpha$ that make hydrogen bonding interactions (yellow ball-and-stick) and form a hydrophobicbinding pocket for $\mathrm{E}_{2}$ (red half-moons). Respective residues that contact $\mathrm{E}_{2}$ in the LMB ERs are identical to $\mathrm{hER} \alpha$ except the bass $\mathrm{ER} \alpha$ contains a methionine (M) instead of a leucine (L) at position 349.

\section{Discussion}

We have previously shown that injection of LMB with increasing concentrations of $\mathrm{E}_{2}$ resulted in the induction of $E R \alpha, E R \beta a$ (to a smaller extent), and vtg1 in liver tissue (Sabo-Attwood et al. 2004), indicating that the impact of $\mathrm{E}_{2}$ on the transcriptional regulation and activation of the different ER isotypes are not identical. The goal of this study was to observe changes in the expression and activity of three LMB ER isotypes and vtg 1 following exposure to the environmental contaminant NP. Based on previous studies, we hypothesized that NP would act as a weak estrogen and induce transcription of $\mathrm{E}_{2}$-activated genes ( $\mathrm{ER} \alpha$ and vtg1) through an ER-mediated process. The production of vtg in male fish has been clearly linked to reproductive impacts in multiple species and populations (Miller et al. 2007). Altered reproductive biomarkers of LMB from contaminated field sites have been documented (Sepulveda et al. 2002, 2003, Schmitt et al. 2005) and causally linked to xenoestrogen exposures (at least in part).

\section{Regulation of LMB ER isotype and vtg1 expression by NP in vivo}

Results from our studies reveal that vtg1 and only ER $\alpha$ mRNA levels were significantly increased following exposure to NP (25 and $50 \mathrm{mg} / \mathrm{kg}$ ), whereas no change in the levels of ERßa and ER $\beta b$ was observed for any of the doses at the time points measured. This is consistent with our previous report showing a strong correlation between the induction of vtg1 and $\mathrm{ER} \alpha$ mRNA during the reproductive cycle of female LMB and in males injected with $\mathrm{E}_{2}$ (Sabo-Attwood et al. 2004). Interestingly, in our previous study, ERßa levels were significantly increased only by our highest dose, $2.5 \mathrm{mg} / \mathrm{kg}$ $\mathrm{E}_{2}$ (Sabo-Attwood et al. 2004). None of the NP doses tested stimulated ERßa levels in the present study, indicating that even the highest dose of NP was much less potent than $2.5 \mathrm{mg} / \mathrm{kg} \mathrm{E}$. Similar levels of $\mathrm{ER} \alpha$ and vtg1 induction were noted in response to $0.5 \mathrm{mg} / \mathrm{kg} \mathrm{E} \mathrm{E}_{2}$ and $50 \mathrm{mg} / \mathrm{kg} \mathrm{NP}$, indicating that NP is $\sim 100$-fold less potent by comparison. Based on this observation, our highest dose of NP would unlikely produce a similar 


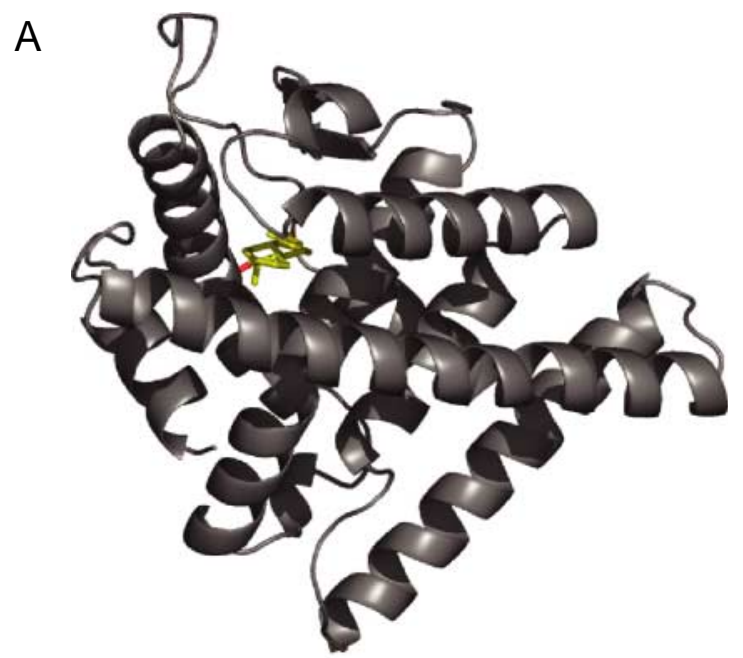

B
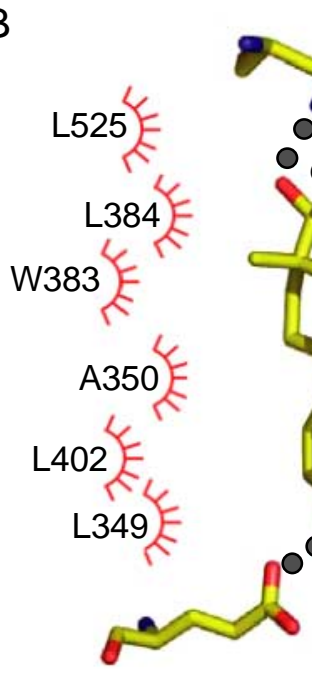

E353
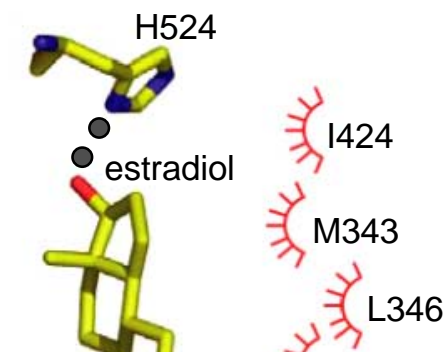
F404

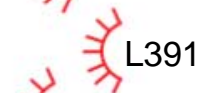
M388

(1)

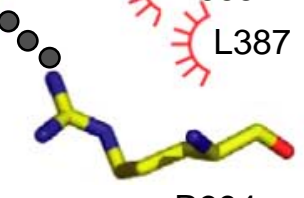

R394

Figure 8 Predicted model of LMB ER $\alpha$ with ligand. (A) Ribbon diagram of LMB ER $\alpha$ with $E_{2}$ bound. Backbone with predicted secondary structure is shown in grey with estradiol in yellow balland-stick. Figure was generated with PyMOL. (B) Molecular interactions of $h E R \alpha$ and $E_{2}$. $E_{2}$ and residues from $h E R \alpha$ that make hydrogen bonding interactions are shown in yellow ball-and-stick and are as labeled. Residues that form a hydrophobic-binding pocket are indicated as red half-moons and are also as labeled. The model was generated with BobScript and rendered with Raster3D. For readers of the printed journal a colour version of this figure can be found at http://dx.doi.org/10.1677/JME-07-0038.

response as $2.5 \mathrm{mg} / \mathrm{kg} \mathrm{E}_{2}$. In a recent study (Filby \& Tyler 2005), aqueous exposures of fathead minnows to $\mathrm{E}_{2}$ failed to induce transcription of ER $\beta \mathrm{a}$ in the liver, suggesting that this isotype is not strongly regulated at the transcriptional level by $\mathrm{E}_{2}$ at the concentrations naturally found in fish throughout the reproductive cycle. It is noteworthy to mention that we have

documented high levels of ERßa (and ER $\beta b$ ) in LMB ovarian tissue when plasma levels of $\mathrm{E}_{2}$ were low, indicating that the transcriptional regulation of the ER $\beta$ s may not be steroidal in nature and is cell-type specific (Sabo-Attwood et al. 2004). In contrast, goldfish ERßa mRNA was inducible by NP in the liver (Soverchia et al. 2005) following chronic water exposure. The reason for this discrepancy is unclear but may be related to route and duration of exposure in the two experiments, or alternatively using primers that did not distinguish the different receptor isotypes. The expression of ER $\alpha$ mRNA was not measured in those previous reports, which seems to be the most highly expressed receptor in response to both $\mathrm{E}_{2}$ and NP in bass and other fish (Filby \& Tyler 2005).

Overall, the similar expression profiles for the three ERs and vtg1 in LMB liver tissue exposed to NP compared with $\mathrm{E}_{2}$, albeit at lower magnitudes, confirms $\mathrm{NP}$ is weakly estrogenic. Furthermore, these data suggest that $\mathrm{ER} \alpha$ is the only isotype strongly autoregulated by estrogens at the transcriptional level in the liver, an observation that may be due to varied promoter-response elements and cell-specific pools of co-effector proteins. Although the transcriptional response of the ERs and vtg1 was similar between $\mathrm{E}_{2}$ and NP, the time-course plots suggest that activation of $\mathrm{ER} \alpha$ and $\operatorname{vtg} 1$ by NP is more sustained. Differences in distribution and clearance of $\mathrm{E}_{2}$ and $\mathrm{NP}$ may contribute to this observation. Increased levels of NP metabolites were detected in LMB bile, consistent with other observations that show biliary excretion is a major route of NP removal from fish (Coldham et al. 1998, Arukwe et al. 2000b). A chief clearance pathway of $\mathrm{E}_{2}$ and NP includes the generation of glucuronide conjugates and it is possible that exposure to NP, especially at high doses, saturates this pathway, resulting in prolonged circulation of $\mathrm{E}_{2}$. This may contribute to the increased levels of plasma $\mathrm{E}_{2}$ observed in NP-treated LMB. This level of induction $(1 \mathrm{ng} / \mathrm{ml})$ is similar to physiological levels seen in female LMB during active reproduction and corresponds to peak levels observed in this species during the annual reproductive cycle. Although NP has been shown to interact directly with the ERs of numerous species (White et al. 1994, Kuiper et al. 1998, Balaguer et al. 1999, Nishikawa et al. 1999, Gale et al. 2004), a few reports have suggested that the estrogenic effects of NP in vivo are the result from altered levels of endogenous steroids (Acevedo et al. 2005, Matsumura et al. 2005, Soverchia et al. 2005). Exposure of fathead minnows to NP also resulted in increased levels of plasma $\mathrm{E}_{2}$ with a concomitant decrease in testosterone (Soverchia et al. 2005). Others have shown that NP enhanced $20 \alpha-$ and $20 \beta$-hydroxysteroid dehydrogenase activities and inhibited glucuronidation pathways involved in the clearance of $\mathrm{E}_{2}$ in carp microsomes (Thibaut \& Porte 2004), and 
increased the expression of aromatase (Cytochrome P450-19; CYP19) in fish (Min et al. 2003, Kazeto et al. 2004) but not in mammalian models (Odum et al. 2001). These observations suggest that NP-induced alterations in steroid synthesis, metabolism, and clearance, in addition to direct activation of ER $\alpha$ contribute to the estrogenic effects of this compound in fish. The role of these individual components in NP-induced endocrine alterations remains to be determined.

\section{Differential activation of LMB ER subtypes by $E_{2}$ and NP}

To understand potential functional differences of the ER isotypes, a reporter gene assay was developed to assess their activity in liver cells. Using this system, we observed little difference for the computed $\mathrm{EC}_{50}$ values among the bass ERs $(106 \cdot 8-134 \cdot 8 \mathrm{nM})$. This is similar to work with zfERs by Bardet et al. (2002). These values are much higher than those reported for the hERs where $\mathrm{EC}_{50}$ values for the $\mathrm{hER} \alpha$ and $\mathrm{hER} \beta$ range from $0 \cdot 1$ to 4 $\mathrm{nM}$ and from 5 to $10 \mathrm{nM}$ respectively, depending on the reporter assay employed (Hall \& McDonnell 1999, Gaido et al. 2000). In general, fish have higher circulating concentrations of $\mathrm{E}_{2}(600-3900 \mathrm{pg} / \mathrm{ml}$ for females (Orlando et al. 1999, Gross et al. 2002, Sabo-Attwood et al. 2004)) in comparison with human females which range from 23 to $361 \mathrm{pg} / \mathrm{ml}$ depending on time of the menstrual cycle (during pregnancy, normal concentration can be as high as $35000 \mathrm{pg} / \mathrm{ml}$; Simpson \& MacDonald 1981). Previous studies have shown that the rainbow trout ER binds $\mathrm{E}_{2}$ with tenfold less affinity than hER, which may be a result of varied protein structure, and may explain why higher levels are noted in fish. Furthermore, it has been suggested that since the body temperature of fish is generally less than in humans, compelling the bass ERs to fold and function normally at $37^{\circ} \mathrm{C}$ in the HepG2 assays may cause them to need far more ligand than what may usually be required by warm-blooded species (Matthews et al. 2001).

Although the $\mathrm{EC}_{50}$ values were similar, the level of activity varied for each $\mathrm{ER}$. $\mathrm{ER} \alpha$ was most responsive to $E_{2}$, followed by $E R \beta b$; whereas ERßa was minimally affected. At equivalent concentrations, ER $\beta b$ activity was approximately half that observed for ER $\alpha$. This is consistent with the differences in activity for the hERs reported previously in HepG2 cells, where the activity of hER $\beta$ was $20-60 \%$ of hER $\alpha$ (Hall \& McDonnell 1999). Since ER $\alpha$ and ER $\beta$ of other species, including mammals and fish, bind $\mathrm{E}_{2}$ with similar affinity, and amino acids that directly interact with $\mathrm{E}_{2}$ are almost identical (Fig. 8), their differential activity is more likely due to distinct interactions with endogenous co-activator and co-repressor proteins.
The effects of the model endocrine disruptor, NP, on transcriptional activation of the bass ERs showed that $\mathrm{ER} \alpha$ and $\mathrm{ER} \beta \mathrm{b}$ respond to NP in a dose-dependent manner, however, ERßa did not. This finding is different from data published by Legler et al. (2002) who found that all three of the zf ERs, including ERßa (ER $\gamma$ in their report) were responsive. The pattern of ER inducibility was also different between bass and zf. Bass $\mathrm{ER} \alpha$ and bass ER $\beta \mathrm{b}$ had $\mathrm{EC}_{50}$ values of 1.052 and $0 \cdot 27$ respectively, compared to values of 1.48 and 0.42 respectively for the zf homologs. Legler et al. (2002) also compared the $\mathrm{zf}$ ER response with $\mathrm{NP}$ with hERs finding $\mathrm{EC}_{50}$ values of $0 \cdot 11$ and $0 \cdot 145 \mu \mathrm{M}$ for $\mathrm{ER} \alpha$ and ER $\beta$ respectively. One reason for the differences in these two reports may be the use of different cell types. Legler et al. used HEK293 cells, while HepG2 cells were used in the present study. Also using HepG2 cells, Yoon et al. (2000) showed that NP can stimulate activity of $\mathrm{hER} \alpha$ via either $\mathrm{AF}-1$ or AF-2 domains using receptor deletion mutants, finding that the AF-1 domain can be activated by lower concentrations of NP than the AF-2 domain. However, the wild-type full-length ER $\alpha$ responded more like the AF-2 domain. Taking these findings into account, the differences in the amino acid composition of the receptor isotypes in the $\mathrm{AF}$ domains may be responsible for the lack of response through ERßa.

\section{Inhibition of ER activity by the antagonists ICI 182780 and ZM 189154}

ER $\alpha$ was inhibited in activity by the ER antagonist ICI 182780 when the cells were treated with tenfold molar excess over $\mathrm{E}_{2}$. When the same treatment was done with the ER $\beta$ s, we did not see a significant decrease in ER $\beta$ a activity and only a $55 \%$ decrease in receptor activity for $\mathrm{ER} \beta \mathrm{b}$, where the activity still remained significantly higher than vehicle. When the receptors were challenged with ZM 189 154, we found the receptors fully inhibited with a tenfold molar excess of inhibitor to ligand. In addition, the ZM compound did not exhibit any agonist activity in these assays. The differences observed in the abilities of the two 'pure' estrogen antagonists to inhibit transactivation of the bass ERs was not anticipated, since amino acid residues known to be involved directly in $\mathrm{E}_{2}$ binding in the LBDs are identical in the three receptors (Fig. 8). There must be other amino acid residues which directly interact with the antagonists and recruit variable pools of co-repressor proteins that contribute to these differences.

\section{Modulation of ER $\alpha$ activity by ER $\beta a$ and $E R \beta b$}

Tremblay et al. (1999) first demonstrated that hER $\alpha / \beta$ heterodimers can occur following treatment in gel shift 
assays from transfected cells. They then showed that when transfected in combination, a $33 \%$ decrease in transcriptional activity through a basal ERE promoter occurred. Hall \& McDonnell (1999) went on to show that by increasing the amount of hER $\beta$, the overall activity of $\mathrm{hER} \alpha$ can be decreased in direct relation to the concentration of hER $\beta$, and that this only occurs at sub-saturating concentrations of $\mathrm{E}_{2}$. This is similar to our findings where the addition of increasing concentrations of either of the ER $\beta$ s with $\mathrm{ER} \alpha$ reduced the amount of transcriptional activity observed with ER $\alpha$ alone. These observations imply that the ratio of ERs in a given cell plays a role in target gene activation. It has been suggested that the AF-1 domain of hER $\beta$ has a repressor function that is the cause of the overall decrease in activity of the $\mathrm{ER} \alpha / \mathrm{ER} \beta$ heterodimeric complex (Hall \& McDonnell 1999). Further studies are needed to address the molecular basis of these observations, but these results stress the importance of cellular composition for ER transcriptional regulation of downstream target genes. We are currently in the process of validating antibodies designed to specifically distinguish the three ERs. These will be useful for many applications in vivo including tissue and subcellular localization of the ERs, dimerization complexes, and assessment of activation by gel shift assays.

\section{Overall conclusions}

Based on the data presented, there is evidence showing that the two ER $\beta$ subtypes in bass are non-redundant, having differing responses to different ligands, and that these in turn are different from ER $\alpha$. Although the mechanistic in vitro data compliment the in vivo observations observed in this study, we realize the complexity of the mechanism in vivo and are aware of two assumptions, which require further testing in vivo. These assumptions are that an increase in mRNA levels of the ERs translates to protein and that the ER isoforms are present in the same cells thereby modulating each others activity in response to ligands. If these assumptions are correct, by altering the amount(s) of receptor present, as well as their activity by agonists and antagonists in the environment, homeostasis in the fish can be seriously compromised, affecting not only the reproductive health, but also the visceral health of this species. The finding that NP did not stimulate ER $\beta \mathrm{a}$ in the assays in this report, indicates that the deleterious effects occurring through ERmediated pathways does not occur through direct activation of ERßa in the liver. Even more broadly, the combinatorial complexity possible with having three distinct ERs in nearly every organ system in the body does suggest that further study of other endocrine active compounds is necessary as proposed by the EPA in the Endocrine Disruptor Screening and Testing Advisory Committee.

\section{Acknowledgements}

The authors would like to thank Pierre Chambon for providing us with the ERE-luciferase construct and Tom Hutchinson and Astra Zeneca, UK for supplying us with the ZM 189154 compound.

\section{Funding}

These studies were supported by the Superfund Basic Research Program from the National Institute of Environmental Health Sciences, P42 ES 07375 and NIEHS RO1 ES015449 to ND and NIH grant GM25154 to RM for salary support of ZF. The authors declare no conflict of interest.

\section{References}

Acevedo R, Parnell PG, Villanueva H, Chapman LM, Gimenez T, Gray SL \& Baldwin WS 2005 The contribution of hepatic steroid metabolism to serum estradiol and estriol concentrations in nonylphenol treated MMTVneu mice and its potential effects on breast cancer incidence and latency. Journal of Applied Toxicology $\mathbf{2 5}$ 339-353.

Allen Y, Matthiessen P, Scott AP, Haworth S, Feist S \& Thain JE 1999 The extent of oestrogenic contamination in the UK estuarine and marine environments-further surveys of flounder. Science of the Total Environment 233 5-20.

Arukwe A, Celius T, Walther BT \& Goksoyr A 2000 $a$ Effects of xenoestrogen treatment on zona radiata protein and vitellogenin expression in Atlantic salmon (Salmo salar). Aquatic Toxicology 49 $159-170$.

Arukwe A, Thibaut R, Ingebrigtsen K, Celius T, Goksoyr A \& Cravedi J $2000 \mathrm{~b}$ In vivo and in vitro metabolism and organ distribution of nonylphenol in Atlantic salmon (Salmo salar). Aquatic Toxicology 49 289-304.

Arukwe A, Yadetie F, Male R \& Goksoyr A 2001 In vivo modulation of nonylphenol-induced zonagenesis and vitellogenesis by the antiestrogen. 3,3 $4,4^{\prime}$-tetrachlorobiphenyl (PCB-77) in juvenile fish. Environmental Toxicology and Pharmacology 10 5-15.

Balaguer P, Francois F, Comunale F, Fenet H, Boussioux AM, Pons M, Nicolas JC \& Casellas C 1999 Reporter cell lines to study the estrogenic effects of xenoestrogens. Science of the Total Environment 233 47-56.

Bardet PL, Horard B, Robinson-Rechavi M, Laudet V \& Vanacker JM 2002 Characterization of oestrogen receptors in zebrafish (Danio rerio). Journal of Molecular Endocrinology 28 153-163.

Blom A, Ekman E, Johannisson A, Norrgren L \& Pesonen M 1998 Effects of xenoestrogenic environmental pollutants on the proliferation of a human breast cancer cell line (MCF-7). Archives of Environmental Contamination and Toxicology 34 306-310.

Bowman CJ, Kroll KJ, Gross TG \& Denslow ND 2002 Estradiol-induced gene expression in largemouth bass (Micropterus salmoides). Molecular and Cellular Endocrinology 196 67-77.

Canadian Environmental Protection Act, 2000 (http://www.ec.gc.ca/ CEPARegistry/the_act/contents.cfm). 
Celius T, Haugen TB, Grotmol T \& Walther BT 1999 A sensitive zonagenetic assay for rapid in vitro assessment of estrogenic potency of xenobiotics and mycotoxins. Environmental Health Perspectives 107 $63-68$.

Coldham NG, Sivapathasundaram S, Dave M, Ashfield LA, Pottinger TG, Goodall C \& Sauer MJ 1998 Biotransformation, tissue distribution, and persistence of 4-nonylphenol residues in juvenile rainbow trout (Oncorhynchus mykiss). Drug Metabolism and Disposition 26 347-354.

Emsley P \& Cowtan K 2004 Coot: model-building tools for molecular graphics. Acta Crystallographica. Section D. Biological Crystallography 60 2126-2132.

Esnouf RM 1999 Further additions to MolScript version 1.4, including reading and contouring of electron-density maps. Acta Crystallographica. Section D. Biological Crystallography 55 938-940.

Filby AL \& Tyler CR 2005 Molecular characterization of estrogen receptors $1,2 \mathrm{a}$ and $2 \mathrm{~b}$ and their tissue and ontogenic expression profiles in fathead minnow (Pimephales promelas). Biology of Reproduction 73 648-662.

Gaido KW, Maness SC, McDonnell DP, Dehal SS, Kupfer D \& Safe S 2000 Interaction of methoxychlor and related compounds with estrogen receptor alpha and beta, and androgen receptor: structure-activity studies. Molecular Pharmacology 58 852-858.

Gale WL, Patino R \& Maule AG 2004 Interaction of xenobiotics with estrogen receptors alpha and beta and a putative plasma sex hormonebinding globulin from channel catfish (Ictalurus punctatus). General and Comparative Endocrinology 136 338-345.

Gray LE Jr, Kelce WR, Wiese T, Tyl R, Gaido K, Cook J, Klinefelter G, Desaulniers D, Wilson E, Zacharewski T et al. 1997 Endocrine Screening Methods Workshop report: detection of estrogenic and androgenic hormonal and antihormonal activity for chemicals that act via receptor or steroidogenic enzyme mechanisms. Reproductive Toxicology 11 719-750.

Gross TS, Wieser CM, Sepúlveda MS, Wiebe JJ, Schoeb TR \& Denslow ND 2002 Characterization of annual reproductive cycles for pond-reared Florida largemouth bass (Micropterus salmoides floridanus). In Black Bas: Ecology, Conservation, and Management, pp 205-212. Eds DP Philipp \& MS Ridgway. Bethesda, MD: American Fisheries Society pp 205-212.

Guex N, Diemand A \& Peitsch MC 1999 Protein modelling for all. Trends in Biochemical Science 24 364-367.

Hall JM \& McDonnell DP 1999 The estrogen receptor beta-isoform (ER $\beta)$ of the human estrogen receptor modulates ER $\alpha$ transcriptional activity and is a key regulator of the cellular response to estrogens and antiestrogens. Endocrinology 140 5566-5578.

Harris CA, Santos EM, Janbakhsh A, Pottinger TG, Tyler CR \& Sumpter JP 2001 Nonylphenol affects gonadotropin levels in the pituitary gland and plasma of female rainbow trout. Environmental Science and Technology 35 2909-2916.

Hawkins MB \& Thomas P 2004 The unusual binding properties of the third distinct teleost estrogen receptor subtype ER $\beta$ are accompanied by highly conserved amino acid changes in the ligand binding domain. Endocrinology 145 2968-2977.

Hawkins MB, Thornton JW, Crews D, Skipper JK, Dotte A \& Thomas P 2000 Identification of a third distinct estrogen receptor and reclassification of estrogen receptors in teleosts. PNAS 97 10751-10756.

Hornung MW, Ankley GT \& Schmieder PK 2003 Induction of an estrogen-responsive reporter gene in rainbow trout hepatoma cells (RTH 149) at 11 or 18 degrees C. Environmental Toxicology and Chemistry 22 866-871.

Jobling S, Beresford N, Nolan M, Rodgers-Gray T, Brighty GC, Sumpter JP \& Tyler CR 2002 Altered sexual maturation and gamete production in wild roach (Rutilus rutilus) living in rivers that receive treated sewage effluents. Biology of Reproduction 66 272-281.
Kannan K, Keith TL, Naylor CG, Staples CA, Snyder SA \& Giesy JP 2003 Nonylphenol and nonylphenol ethoxylates in fish, sediment, and water from the Kalamazoo River, Michigan. Archives of Environmental Contamination and Toxicology 44 77-82.

Kazeto Y, Place AR \& Trant JM 2004 Effects of endocrine disrupting chemicals on the expression of CYP19 genes in zebrafish (Danio rerio) juveniles. Aquatic Toxicology 69 25-34.

Kuiper GG, Lemmen JG, Carlsson B, Corton JC, Safe SH, van der Saag PT, van der Burg B, Gustafsson JA, van der Saag PT, van der Burg B et al. 1998 Interaction of estrogenic chemicals and phytoestrogens with estrogen receptor beta. Endocrinology 139 4252-4263.

Latonnelle K, Le Menn F, Kaushik SJ \& Bennetau-Pelissero C 2002 Effects of dietary phytoestrogens in vivo and in vitro in rainbow trout and Siberian sturgeon: interests and limits of the in vitro studies of interspecies differences. General and Comparative Endocrinology 126 $39-51$.

Laws SC, Carey SA, Ferrell JM, Bodman GJ \& Cooper RL 2000 Estrogenic activity of octylphenol, nonylphenol, bisphenol A and methoxychlor in rats. Toxicological Sciences 54 154-167.

Lee PC 1998 Disruption of male reproductive tract development by administration of the xenoestrogen, nonylphenol, to male newborn rats. Endocrine 9 105-111.

Legler J, Zeinstra LM, Schuitemaker F, Lanser PH, Bogerd J, Brouwer A, Vethaak AD, De Voogt P, Murk AJ \& Van der Burg B 2002 Comparison of in vivo and in vitro reporter gene assays for shortterm screening of estrogenic activity. Environmental Science and Technology 36 4410-4415.

Lin LL \& Janz DM 2006 Effects of binary mixtures of xenoestrogens on gonadal development and reproduction in zebrafish. Aquatic Toxicology 80 382-395.

Matsumura N, Ishibashi H, Hirano M, Nagao Y, Watanabe N, Shiratsuchi H, Kai T, Nishimura T, Kashiwagi A \& Arizono K 2005 Effects of nonylphenol and triclosan on production of plasma vitellogenin and testosterone in male South African clawed frogs (Xenopus laevis). Biological and Pharmaceutical Bulletin 28 1748-1751.

Matthews JB, Clemons JH \& Zacharewski TR 2001 Reciprocal mutagenesis between human alpha(L349, M528) and rainbow trout (M317, I496) estrogen receptor residues demonstrates their importance in ligand binding and gene expression at different temperatures. Molecular and Cellular Endocrinology 183 $127-139$.

Metcalfe CD, Metcalfe TL, Kiparissis Y, Koenig BG, Khan C, Hughes RJ, Croley TR, March RE \& Potter T 2001 Estrogenic potency of chemicals detected in sewage treatment plant effluents as determined by in vivo assays with Japanese medaka (Oryzias latipes). Environmental Toxicology and Chemistry 20 297-308.

Miller DH, Jensen KM, Villeneuve DL, Kahl MD, Makynen EA, Durhan EJ \& Ankley GT 2007 Linkage of biochemical responses to population-level effects: a case study with vitellogenin in the fathead minnow (Pimephales promelas). Environmental Toxicology and Chemistry 26 521-527.

Min J, Lee SK \& Gu MB 2003 Effects of endocrine disrupting chemicals on distinct expression patterns of estrogen receptor, cytochrome P450 aromatase and $p 53$ genes in oryzias latipes liver. Journal of Biochemical and Molecular Toxicology 17 272-277.

Morito K, Hirose T, Kinjo J, Hirakawa T, Okawa M, Nohara T, Ogawa S, Inoue S, Muramatsu M \& Masamune Y 2001 Interaction of phytoestrogens with estrogen receptors $\alpha$ and $\beta$. Biological and Pharmaceutical Bulletin 24 351-356.

Nimrod AC \& Benson WH 1996 Environmental estrogenic effects of alkylphenol ethoxylates. Critical Reviews in Toxicology 26 335-364.

Nishikawa J, Saito K, Goto J, Dakeyama F, Matsuo M \& Nishihara T 1999 New screening methods for chemicals with hormonal activities using interaction of nuclear hormone receptor with coactivator. Toxicology and Applied Pharmacology 154 76-83. 
Oakes KD, Hewitt LM, McMaster ME, Wood C, Munkittrick KR \& Van Der Kraak GJ 2005 Oxidative stress and sex steroid levels in fish following short-term exposure to pulp-mill effluents. Journal of Toxicology and Environmental Health. Part A A68 267-286.

Odum J, Tinwell H, Van Miller J, Joiner R \& Ashby J 2001 The uterotrophic activity of nonylphenol in the rat is not mediated by aromatase enzyme induction. Toxicology Letters 118 165-169.

Orlando EF, Denslow ND, Folmar LC \& Guillette LJ Jr. 1999 A comparison of the reproductive physiology of largemouth bass. Micropterus salmoides, collected from the Escambia and Blackwater Rivers in Florida. Environmental Health Perspectives 107 199-204.

Peitsch MC 1996 ProMod and Swiss-Model: internet-based tools for automated comparative protein modelling. Biochemical Society Transactions 24 274-279.

Pettersson M, Adolfsson-Erici M, Parkkonen J, Forlin L \& Asplund L 2005 Fish bile used to detect estrogenic substances in treated sewage water. Science of the Total Environment 366 174-186.

Radice S, Fumagalli R, Chiesara E, Ferraris M, Frigerio S \& Marabini L 2004 Estrogenic activity of procymidone in rainbow trout (Oncorhynchus mykiss) hepatocytes: a possible mechanism of action. Chemico-Biological Interactions 147 185-193.

Sabik H, Gagne F, Blaise C, Marcogliese DJ \& Jeannot R 2003 Occurrence of alkylphenol polyethoxylates in the St Lawrence River and their bioconcentration by mussels (Elliptio complanata). Chemosphere 51 349-356.

Sabo-Attwood T, Kroll KJ \& Denslow ND 2004 Differential expression of largemouth bass (Micropterus salmoides) estrogen receptor isotypes alpha, beta, and gamma by estradiol. Molecular and Cellular Endocrinology 218 107-118.

Schmitt CJ, Hinck JE, Blazer VS, Denslow ND, Dethloff GM, Bartish TM, Coyle JJ \& Tillitt DE 2005 Environmental contaminants and biomarker responses in fish from the Rio Grande and its US tributaries: spatial and temporal trends. Science of the Total Environment 350 161-193.

Schwaiger J, Mallow U, Ferling H, Knoerr S, Braunbeck T, Kalbfus W \& Negele RD 2002 How estrogenic is nonylphenol? A transgenerational study using rainbow trout (Oncorhynchus mykiss) as a test organism Aquatic Toxicology 59 177-189.

Schwede T, Kopp J, Guex N \& Peitsch MCSWISS-MODEL: 2003 An automated protein homology-modeling server. Nucleic Acid Research 31 3381-3385.

Scott MJ \& Jones MN 2000 The biodegradation of surfactants in the environment. Biochimica et Biophysica Acta 1508 235-251.

Seki M, Yokota H, Maeda M, Tadokoro H \& Kobayashi K 2003 Effects of 4-nonylphenol and 4-tert-octylphenol on sex differentiation and vitellogenin induction in medaka (Oryzias latipes). Environmental Toxicology and Chemistry 22 1507-1516.

Sepulveda MS, Johnson WE, Higman JC, Denslow ND, Schoeb TR \& Gross TS 2002 An evaluation of biomarkers of reproductive function and potential contaminant effects in Florida largemouth bass (Micropterus salmoidesfloridanus) sampled from the St Johns River. Science of the Total Environment 289 133-144.
Sepulveda MS, Quinn BP, Denslow ND, Holm SE \& Gross TS 2003 Effects of pulp and paper mill effluents on reproductive success of largemouth bass. Environmental Toxicology and Chemistry 22 205-213.

Simpson ER \& MacDonald PC 1981 Endocrine physiology of the placenta. Annual Review of Physiology 43 163-188.

Sohoni P \& Sumpter JP 1998 Several environmental oestrogens are also anti-androgens. Journal of Endocrinology 158 327-339.

Soto AM, Sonnenschein C, Chung KL, Fernandez MF, Olea N \& Serrano FO 1995 The E-SCREEN assay as a tool to identify estrogens: an update on estrogenic environmental pollutants. Environmental Health Perspectives 103 113-122.

Soverchia L, Ruggeri B, Palermo F, Mosconi G, Cardinaletti G, Scortichini G, Gatti G \& Polzonetti-Magni AM 2005 Modulation of vitellogenin synthesis through estrogen receptor beta-1 in goldfish (Carassius auratus) juveniles exposed to 17- $\beta$ estradiol and nonylphenol. Toxicology and Applied Pharmacology 209 236-243.

Tanenbaum DM, Wang Y, Williams SP \& Sigler PB 1998 Crystallographic comparison of the estrogen and progesterone receptor's ligand binding domains. PNAS A95 5998-6003.

Thibaut R \& Porte C 2004 Effects of endocrine disrupters on sex steroid synthesis and metabolism pathways in fish. Journal Steroid Biochemistry and Molecular Biology 92 485-494.

Thorpe KL, Hutchinson TH, Hetheridge MJ, Scholze M, Sumpter JP \& Tyler CR 2001 Assessing the biological potency of binary mixtures of environmental estrogens using vitellogenin induction in juvenile rainbow trout (Oncorhynchus mykiss). Environmental Science and Technology 35 2476-2481.

Tremblay GB, Tremblay A, Labrie F \& Giguere V 1999 Dominant activity of activation function 1 (AF-1) and differential stoichiometric requirements for AF-1 and -2 in the estrogen receptor $\alpha-\beta$ heterodimeric complex. Molecular and Cellular Biology 19 1919-1927.

White R, Jobling S, Hoare SA, Sumpter JP \& Parker MG 1994 Environmentally persistent alkylphenolic compounds are estrogenic. Endocrinology 135 175-182.

Wilson VS, Bobseine K \& Gray LE Jr. 2004 Development and characterization of a cell line that stably expresses an estrogen-responsive luciferase reporter for the detection of estrogen receptor agonist and antagonists. Toxicological Sciences $81 \quad 69-77$.

Yoon K, Pellaroni L, Ramamoorthy K, Gaido K \& Safe S 2000 Ligand structure-dependent differences in activation of estrogen receptor alpha in human HepG2 liver and U2 osteogenic cancer cell lines. Molecular and Cellular Endocrinology 162 211-220.

Received in final form 3 June 2007

Accepted 20 July 2007

Made available online as an Accepted Preprint

2 August 2007 